\title{
Topographical expression of class IA and class II phosphoinositide 3-kinase enzymes in normal human tissues is consistent with a role in differentiation
}

\author{
Soha Salama El Sheikh1, Jan Domin², Prakitpunthu Tomtitchong1, \\ Paul Abel ${ }^{3}$, Gordon Stamp ${ }^{1}$ and El-Nasir Lalani*1
}

\author{
Address: ${ }^{1}$ Department of Histopathology, L Block, Hammersmith Hospital Campus, Imperial College, London W12 0NN, UK, ${ }^{2}$ Department of \\ Renal Medicine, J Block, Hammersmith Hospital Campus, Imperial College, London W12 0NN, UK and ${ }^{3}$ Department of Surgery, B Block, \\ Hammersmith Hospital Campus, Imperial College, London W12 0NN, UK \\ Email: Soha Salama El Sheikh - soha.el-sheikh@imperial.ac.uk; Jan Domin - j.domin@imperial.ac.uk; \\ Prakitpunthu Tomtitchong -drpom@hotmail.com; Paul Abel - p.abel@imperial.ac.uk; Gordon Stamp - g.stamp@imperial.ac.uk; El- \\ Nasir Lalani* - e.lalani@imperial.ac.uk \\ * Corresponding author
}

Published: 16 October 2003

BMC Clinical Pathology 2003, 3:4

This article is available from: http://www.biomedcentral.com/l472-6890/3/4

(C) 2003 El Sheikh et al; licensee BioMed Central Ltd. This is an Open Access article: verbatim copying and redistribution of this article are permitted in all media for any purpose, provided this notice is preserved along with the article's original URL.

\begin{abstract}
Background: Growth factor, cytokine and chemokine-induced activation of PI3K enzymes constitutes the start of a complex signalling cascade, which ultimately mediates cellular activities such as proliferation, differentiation, chemotaxis, survival, trafficking, and glucose homeostasis. The PI3K enzyme family is divided into 3 classes; class I (subdivided into IA and IB), class II (PI3K-C2 $\alpha$, PI3K-C2 $\beta$ and PI3K-C2 $\gamma$ ) and class III PI3K. Expression of these enzymes in human tissue has not been clearly defined.
\end{abstract}

Methods: In this study, we analysed the immunohistochemical topographical expression profile of class IA (antip85 adaptor) and class II PI3K (PI3K-C2 $\alpha$ and PI3K-C2 $\beta$ ) enzymes in 104 formalin-fixed, paraffin embedded normal adult human (age 33-7I years, median 44 years) tissue specimens including those from the gastrointestinal, genitourinary, hepatobiliary, endocrine, integument and lymphoid systems. Antibody specificity was verified by Western blotting of cell lysates and peptide blocking studies. Immunohistochemistry intensity was scored from undetectable to strong.

Results: PI3K enzymes were expressed in selected cell populations of epithelial or mesenchymal origin. Columnar epithelium and transitional epithelia were reactive but mucous secreting and stratified squamous epithelia were not. Mesenchymal elements (smooth muscle and endothelial cells) and glomerular epithelium were only expressed PI3K-C2 $\alpha$ while ganglion cells expressed $\mathrm{p} 85$ and PI3K-C2 $\beta$. All three enzymes were detected in macrophages, which served as an internal positive control. None of the three PI3K isozymes was detected in the stem cell/progenitor compartments or in B lymphocyte aggregates.

Conclusions: Taken together, these data suggest that PI3K enzyme distribution is not ubiquitous but expressed selectively in fully differentiated, non-proliferating cells. Identification of the normal in vivo expression pattern of class IA and class II PI3K paves the way for further analyses which will clarify the role played by these enzymes in inflammatory, neoplastic and other human disease conditions. 


\section{Background}

Phosphatidylinositol 3-kinases (PI3Ks) were first identified as enzymes associated with various oncoproteins and growth factor receptors [1]. Evidence soon accumulated that PI3Ks can provide a critical signal for cell proliferation, cell survival, membrane trafficking, glucose transport, neurite outgrowth, membrane ruffling, and superoxide production as well as actin reorganization and chemotaxis [2,3]. The diverse range of PI3K functional effects reflects its activation by multiple receptors, the existence of a PI3K enzyme family, and multiple effector proteins that can interact with PI3K lipid products by distinct structural motifs [4]. Mammalian PI3Ks are divided into three classes based on their structure and substrate specificity [5]. Class I enzymes are acutely activated by a variety of cell-surface receptors, and are responsible for synthesis of intracellular phosphatidylinositol $(3,4,5)$-trisphosphate (PtdIns $(3,4,5) \mathrm{P}_{3}$ ) [4]. Class I PI3Ks are divided into two types. Class IA consists of a p110 catalytic subunit that associates with an $\mathrm{SH} 2$ domain-containing subunit: p85 (and its splice variants: p55 and p50). The p85 subunit is considered the most abundant of the class IA regulatory subunits. The majority of tyrosine kinase coupled transmembrane receptors can activate class IA PI3K, although there is a clear variation in the strength and duration of the resulting signals [2]. The only class IB PI3K identified to date is the p110 $\gamma$ catalytic subunit complexed with a p101 regulatory protein and activated by heterotrimeric $\mathrm{G}$ proteins. Class IB PI3K is largely observed in white blood cells [6] with some expression in murine prostate, kidney, exocrine pancreas and salivary glands [7]. PI3K-dependent accumulation of PtdIns $(3,4,5) \quad \mathrm{P}_{3}$ initiated a multitude of downstream signals that include suppression of apoptosis, reorganization of the actin cytoskeleton, cardiac myocyte growth, glycogen synthase stimulation by insulin, TNF-mediated neutrophil priming and superoxide generation, and leukocyte migration and adhesion to endothelial cells $[2,8]$. In contrast to class I PI3Ks, which are mainly cytosolic, class II PI3Ks are predominantly associated with membrane fractions of cells [4]. Enzymes of this class are larger than class I or III PI3Ks, bind adaptor proteins via proline rich regions present within their $\mathrm{N}$-terminal sequence [9]. The association of class II PI3K enzymes with cellular membrane compartments might suggest participation of these enzymes in sorting events or vesicle formation [10]. However, it has recently become evident that a variety of membrane receptors, including tyrosine kinases [insulin, epidermal growth factor receptor (EGFR), platelet derived growth factor receptor (PDGFR)] integrins and a chemokine, monocyte chemotactic peptide-1 (MCP-1), can activate the class II kinases [11-13]. Based on work with cell lines and Northern blotting, expression of PI3K-C $2 \alpha$, PI3K-C2 $\beta$ isoforms was considered ubiquitous $[14,15]$, whilst PI3K-C2 $\gamma$ was mainly found in the liver $[16,17]$.
Class III PI3K is homologous to the saccharomyces cervisiae Vps34p. It is a constitutively active enzyme whose product phosphatidylinositol-3-phosphate (PtdIns (3) P) plays an essential role in protein trafficking through the lysosome [18].

Extensive insight into the PI3K signalling network has been gained through the use of PI3K inhibitors, overexpression approaches, gene targeting studies and microinjection of PI3K antibodies into cells $[2,4,19]$. Whilst these methodologies have assigned roles for PI3K enzyme activity, there is little evidence for critical non-redundant functions of individual enzyme subclasses. Fundamental to the understanding of PI3K enzyme specificity is therefore a robust definition and comparison of the pattern of PI3K expression in human tissues. The existence of multiple classes of PI3K enzymes and several isoforms within each class (class IA/IB, PI3K-C2 $\alpha$, PI3K-C2 $\beta$, PI3K-C2 $\gamma$ ) suggests significant signalling redundancy potentially manifesting in tissue/cell type specific expression. Identification of tissues in which individual or multiple PI3K isoforms are expressed could provide clues to the role or regulation of PI3K enzymes in vivo and identify more relevant in vitro systems to study these enzymes. Furthermore, recognition of PI3K tissue expression has clinical relevance as it would assist in developing targeted therapies utilising PI3K inhibitors.

In this study, we analyze and describe the topographical and semi-quantitate the level of expression of three PI3K isoforms (IA PI3K (p85), PI3K-C2 $\alpha$ and PI3K-C2 $\beta$ ), which are considered to be widely distributed (data based on in vitro studies), in a range of normal human tissues using immunohistochemical techniques.

\section{Methods \\ Tissue Specimens}

The study was approved by the Hammersmith, Queen Charlotte's and Chelsea hospitals research ethics committee. A total of 104 adult normal human tissues specimens from the gastrointestinal (GI), respiratory, reproductive and genitourinary tracts were investigated for the expression of PI3K enzymes. Samples were obtained from the archives of the Department of Histopathology, Hammersmith Hospital, London. $4 \mu \mathrm{m}$ thick serial sections were cut and mounted on Vectabond ${ }^{\mathrm{TM}}$-coated slides for immunohistochemistry.

\section{Antibodies}

Expression of class I PI3K was investigated using an antiPI3K monoclonal antibody (anti-p85) (BD Biosciences (Lexington, KY)) and for PI3K-C2 $\alpha$ and PI3K-C2 $\beta$, polyclonal rabbit antisera were generated as described previously $[11,14]$. Briefly, N-terminal fragments of PI3K-C2 $\alpha$ and PI3K-C2 $\beta$ were expressed as GST fusion proteins and 
used immunize rabbits at monthly intervals. One week after each injection, serum was obtained and its ability to immunoprecipitate and Western blot its corresponding protein was confirmed. For this study, each antibody was affinity purified using the respective fusion protein crosslinked onto glutathione-sepharose beads. To deplete antiGST reactive antibodies, each eluate was incubated with an excess of GST immobilised on glutathione sepharose beads and the supernatant recovered.

Anti-CD68 (PG-M1) (Dako, Denmark) was used in selected sections to identify macrophages in mononuclear cell populations.

\section{Immunohistochemistry (IHC)}

Before embarking on the study, dilution curves, microwave antigen retrieval schedules and enzymatic digestions, were determined for all antibodies used in this study (data not shown). Routinely formaldehyde-fixed, paraffin embedded tissues were deparaffinized, rehydrated in graded alcohols, and stained using the avidinbiotin immunoperoxidase method. Antigen retrieval was performed for $15 \mathrm{~min}$ in $10 \mathrm{mM}$ citrate buffer ( $\mathrm{pH} \mathrm{6)}$ on all sections either in a microwave oven (Whirlpool 750 watts) for anti-p85 antibody or in an autoclave (Prestige Medical, UK) for the class II PI3K antibodies. Sections were allowed to cool at room temperature and endogenous peroxidase was blocked by $0.03 \% \mathrm{H}_{2} \mathrm{O}_{2}$. In the case of PI3K-C2 antibodies, serum blocking (normal goat serum (DAKO, Denmark)) and avidin-biotin blocking (Vector laboratories, USA) preceded the application of primary antibodies. The primary antibodies were diluted in PBS (Phosphate buffered saline (PBS pH 7.2+/-0.2 containing $0.1 \% \mathrm{BSA} / 0.1 \%$ sodium azide) p85 $(1 \mu \mathrm{g} / \mathrm{ml})$, PI3K-C2 $\alpha(1: 400)$ and PI3K-C2 $\beta(1: 600)$ and incubated overnight at $4{ }^{\circ} \mathrm{C}$. To detect p85 expression, the DAKO Envision $^{\mathrm{TM}}$ Kit was used according to the manufacturer's instructions while a secondary goat anti-rabbit antibody (DAKO) followed by avidin-biotin peroxidase (Vector Elite ABC kit, Vector Laboratories, Inc., Burlingame, CA) were used for detection of PI3K-C2. Reactivity was visualised using 3' diaminobenzidine (DAB), which produces a brown reaction product and then lightly counterstained in haematoxylin. Control slides, where the primary antibody was substituted with PBS or diluted non-immune mouse or rabbit IgG were checked for non-specific reactivity before assessment of the staining intensity and percentage of positive cells.

\section{Determination of class II PI3K antibody specificity}

PI3K antibodies were used for Western blotting on cell lysates prepared from breast (MCF-7, T47D) and prostate (CWR22Rv1, LNCaP, PC3 and DU145) cancer cell lines as previously described [9]. Dilutions used were $0.1 \mu \mathrm{g} / \mathrm{ml}$ for p85 and $0.4 \mu \mathrm{g} / \mathrm{ml}$ for anti-class II PI3K antibodies. To confirm the specificity of the immunoreactive signal detected by IHC, serial dilutions of the PI3K-C2 $\alpha$ peptide fragment $(0.05-0.2 \mathrm{mg} / \mathrm{ml})$ and the PI3K-C2 $\beta$ peptide fragment $(0.08-0.5 \mathrm{mg} / \mathrm{ml})$ were pre-incubated with their corresponding antibody for 2 hours at room temperature prior to immunostaining. To exclude reactivity with the GST fusion fragment of the antigenic peptide, antibodies were pre-incubated with GST prior to IHC. PI3K-C $2 \alpha$ was pre-incubated with excess of PI3K-C2 $\beta$ peptide and vice versa to identify cross-reactivity between the PI3K-C2 antibodies. As an additional control, an irrelevant peptide (COX-2 peptide (Cayman Chemical, USA) $0.05-0.5 \mathrm{mg} /$ $\mathrm{ml}$ ) was pre-incubated with the class II antibodies prior to staining of sections.

\section{Assessment of Immunoreactivity}

Intensity of PI3K immunoreactivity was quantified by two independent investigators (SES and PT) using a visual scoring scale (- undetectable; + weak; ++ moderate; +++ strong). The distribution of staining was considered membranous, cytoplasmic or nuclear, homogenous or heterogenous. In case of cytoplasmic expression, diffuse or granular appearance was recorded. Photomicrographs were captured using a DP12 Olympus camera (Olympus, UK) fitted on a Leitz Dialux 22 microscope (Leica microsystems, UK) at the indicated magnification.

\section{Results \\ Confirmation Of Antibody Specificity}

Each of the three antibodies recognised a single protein band of the appropriate size on Western blotting (Figure 1A). Neither of the class II PI3K antibodies have previously been assessed for their reactivity on fixed human tissues. To verify the specificity of PI3K-C2 immunoreactivity, blocking studies were performed by pre-incubation of each antibody with the protein fragment used to raise it prior to its application in IHC. This abolished class II PI3K antibody staining (Figure $1 \mathrm{~B}, 1 \mathrm{C}, 1 \mathrm{D}, 1 \mathrm{E})$. Pre-incubation with equivalent concentrations of GST or an irrelevant peptide had no effect on immunostaining confirming specificity to each $\mathrm{N}$-terminal PI3K-C2 sequence. Pre-incubation of PI3K-C2 $\alpha$ antibody with $N$-terminal PI3K-C2 $\beta$ protein or PI3K-C2 $\beta$ antibody with $\mathrm{N}$-terminal PI3K-C2 $\alpha$ protein (at concentrations which completely blocked staining from its corresponding antibody) did not reduce the intensity of staining with antibody (data not shown). Negative control sections incubated with non-immune IgG or PBS were included with each experiment and were consistently negative.

\section{PI3K Expression Profile in Normal Human Tissues}

Expression of the class I p85 adaptor and class II PI3K were assessed in 104 normal adult human samples using the above antibodies. Expression of these enzymes was 

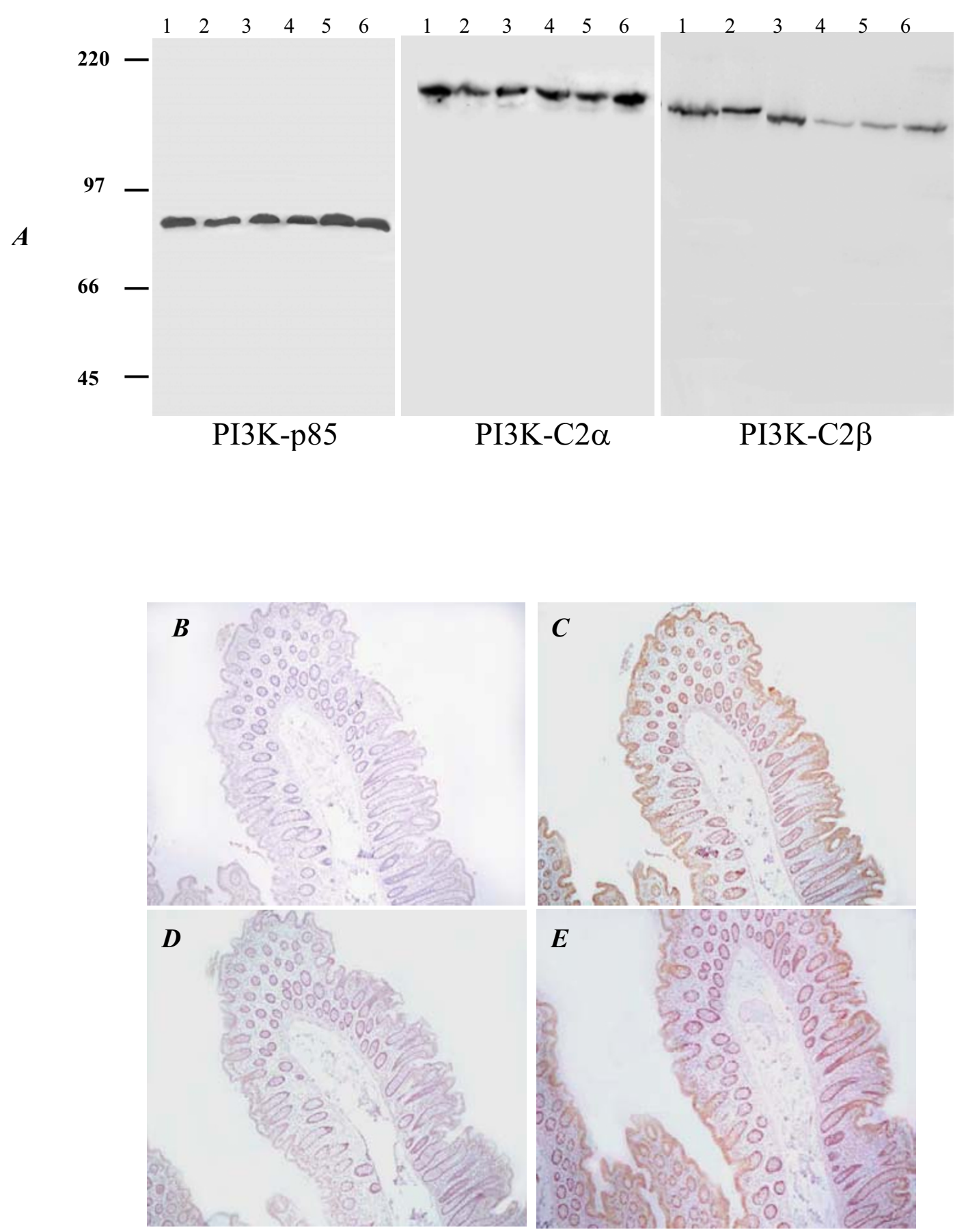

\section{Figure I}

Specificity of immunohistochemical detection of the PI3K-C2 enzymes using antibodies raised against class II N-terminal peptide fragments. Lysates from breast (MCF-7 and T47D, lanes I and 2) and prostate (CWR22RvI, LNCaP, PC3 and DUI45 cells, lanes 3-6 respectively) cancer cell lines were probed for PI3K antibodies (P85, PI3K-C2 $\alpha$ and PI3K-

$\mathrm{C} 2 \beta)$. Molecular weight markers in KDa are indicated on the left. In the lower panels, representative PI3K-C2 $\alpha$ and PI3K-C2 $\beta$ labelled sections with ( $\boldsymbol{B}$ and $\boldsymbol{D}$ respectively) or without pre-absorption of each antibody with its antigenic peptide $(0.1 \mathrm{mg} / \mathrm{ml}$ of $\mathrm{N}$-terminal PI3K-C2 $\alpha$ in $C$ and $0.5 \mathrm{mg} / \mathrm{ml}$ of $\mathrm{N}$-terminal PI3K-C2 $\beta$ in $E$ ) are presented. Original magnification (A-D $\times 200$ ). 
Table I: PI3K expression patterns in normal human tissues.

\begin{tabular}{|c|c|c|c|c|c|c|}
\hline Human Tissues & $\mathbf{n}$ & Histological Structure & p85 & PI3K-C2 $\alpha$ & PI3K-C2 $\beta$ & Figure \\
\hline \multicolumn{7}{|l|}{ Digestive system } \\
\hline \multirow[t]{3}{*}{ Stomach } & 3 & Peptic (chief) cells & +++ & ++ & ++ & $2 A$ \\
\hline & & Parietal (oxyntic) cells & - & - & - & \\
\hline & & Gastric mucous cells & - & - & - & \\
\hline \multirow[t]{3}{*}{ Small intestine } & 7 & Enterocytes & +++ & ++ & + & $2 B$ \\
\hline & & Paneth cells & ++ & - & - & \\
\hline & & Goblet cells & - & - & - & \\
\hline \multirow[t]{2}{*}{ Colon } & 10 & Colonocytes & ++ & ++ & ++ & $2 \mathrm{C}$ \\
\hline & & Goblet cells & - & - & - & \\
\hline \multirow[t]{5}{*}{ Features common to all GIT } & & Mononuclear cells & +++ & ++ & +++ & $2 \mathrm{D}$ \\
\hline & & Muscular layers & - & ++ & - & \\
\hline & & Ganglion cells & +++ & - & +++ & $2 \mathrm{E}$ \\
\hline & & Non-myelinated nerves & - & - & ++ & $2 \mathrm{E}$ \\
\hline & & Neuroendocrine cells & - & - & - & \\
\hline \multicolumn{7}{|l|}{ Respiratory system } \\
\hline \multirow[t]{2}{*}{ Lung } & 5 & Pneumocytes (Types I and II) & - & - & - & \\
\hline & & Alveolar Macrophages & ++ & ++ & ++ & $2 \mathrm{~F}$ \\
\hline \multirow[t]{4}{*}{ Bronchi } & & Bronchial Epithelium & + & + & + & \\
\hline & & Bronchial glands & - & - & - & \\
\hline & & Cartilage & - & - & - & \\
\hline & & Bronchial smooth muscle & - & ++ & - & \\
\hline \multirow[t]{7}{*}{ Skin and Integument } & 5 & Stratified squamous epithelium & - & - & - & $2 \mathrm{G}$ \\
\hline & & Melanocytes & - & - & - & \\
\hline & & Sebaceous glands & + & - & - & $2 \mathrm{G}$ \\
\hline & & Hair follicle & + & - & - & $2 \mathrm{H}$ \\
\hline & & Sweat Glands & + & + & - & $2 \mathrm{H}$ \\
\hline & & Langerhans cells & ++ & - & - & 21 \\
\hline & & Dermal macrophages & ++ & ++ & ++ & 21 \\
\hline \multicolumn{7}{|c|}{ Female reproductive system } \\
\hline \multirow[t]{4}{*}{ Uterus } & 3 & Proliferative Endometrium & ++ & - & - & 2] \\
\hline & 3 & Secretory Endometrium & + & - & - & $2 \mathrm{~K}$ \\
\hline & & Endometrial Stroma & - & - & - & \\
\hline & & Myometrium & - & ++ & - & \\
\hline \multirow[t]{3}{*}{ Cervix } & 3 & Ectocervical squamous epithelium & - & - & - & \\
\hline & & Endocervical glands & - & - & - & $2 \mathrm{~L}$ \\
\hline & & Cervical smooth muscle & - & ++ & - & \\
\hline \multirow[t]{4}{*}{ Ovary } & 3 & Follicular cells & ++ & + & + & $2 M$ \\
\hline & & Germinal cells & - & - & - & \\
\hline & & Stromal cells & - & - & - & \\
\hline & & Corpus luteum & ND & ND & ND & \\
\hline Fallopian tube & 2 & Columnar ciliated epithelium & +++ & ++ & + & $2 \mathrm{~N}$ \\
\hline \multirow[t]{3}{*}{ Mammary gland (breast) } & 3 & Luminal acinar epithelium & - & - & - & 20 \\
\hline & & Myoepithelial cells & - & + & - & \\
\hline & & Lactiferous ducts & - & + & - & \\
\hline \multicolumn{7}{|l|}{ Male reproductive system } \\
\hline \multirow[t]{3}{*}{ Testis } & 3 & Spermatogenic cells & +++ & - & $+++*$ & $2 \mathrm{P}, 2 \mathrm{Q} *$ \\
\hline & & Sertoli cells & - & - & - & \\
\hline & & Leydig cells & ++ & +++ & ++ & \\
\hline Prostate gland & 10 & Basal Epithelium & - & + & - & \\
\hline & & Luminal epithelium & - & - & - & \\
\hline & & Fibromuscular stroma & - & ++ & - & \\
\hline Urinary & & & & & & \\
\hline Urinary bladder & 5 & Transitional epithelium & ++ & ++ & ++ & $2 R$ \\
\hline & & Muscularis & - & ++ & - & \\
\hline Kidney & 10 & Glomerular macrophages & ++ & - & ++ & $3 \mathrm{~A}$ \\
\hline & & Glomerular tuft & - & +++ & - & $3 B$ \\
\hline & & Proximal Tubules & - & + & + & \\
\hline & & Macula Densa & ++ & - & - & $3 \mathrm{~A}$ \\
\hline & & Distal tubules & - & + & + & \\
\hline
\end{tabular}


Table I: PI3K expression patterns in normal human tissues. (Continued)

\begin{tabular}{|c|c|c|c|c|c|c|}
\hline & & Collecting tubules & +++ & + & + & \\
\hline \multirow[t]{3}{*}{ Pancreas } & 5 & Acini & +++ & ++ & - & $3 C, 3 D$ \\
\hline & & Ducts & - & ++ & - & $3 \mathrm{D}$ \\
\hline & & Islets of Langerhans & - & - & - & $3 C$ \\
\hline \multicolumn{7}{|c|}{ Hepatobiliary system } \\
\hline \multirow[t]{3}{*}{ Liver } & 4 & Hepatocytes & - & - & - & \\
\hline & & Bile ducts & - & ++ & - & \\
\hline & & Kupffer cells & - & - & - & \\
\hline \multirow[t]{3}{*}{ Gall bladder } & 4 & Lining epithelium & + & + & + & \\
\hline & & Smooth muscle layer & - & ++ & - & \\
\hline & & Mononuclear cells & ++ & ++ & ++ & \\
\hline \multicolumn{7}{|l|}{ Endocrine System } \\
\hline Thyroid & 3 & Follicular/Parafollicular & - & - & - & \\
\hline Parathyroid & 3 & Oxyphil/Chief & - & - & - & \\
\hline Endocrine Pancreas & & Islets of Langerhans & - & - & - & \\
\hline \multicolumn{7}{|c|}{ Lymphoid tissue \& Immune cells } \\
\hline \multirow[t]{3}{*}{ Spleen } & 5 & White pulp & - & - & - & \\
\hline & & Red pulp (mononuclear cells) & ++ & + & ++ & $3 E$ \\
\hline & & Red pulp (splenic sinusoids) & - & +++ & - & $3 F$ \\
\hline \multirow[t]{5}{*}{ Lymph nodes } & 5 & Lymphoid follicles & - & - & - & \\
\hline & & $\begin{array}{l}\text { Germinal centre mononuclear } \\
\text { cells }\end{array}$ & ++ & + & + & \\
\hline & & Medulla (mononuclear cells) & ++ & + & ++ & \\
\hline & & Tissue macrophages & +++ & ++ & ++ & $3 G$ \\
\hline & & Polymorphnuclear leucocytes & + & +++ & - & $3 \mathrm{H}$ \\
\hline
\end{tabular}

Abbreviations and symbols used: ND: Not determined; - undetectable; + weak; ++ moderate or +++ strong. Reactivity for PI3K-C2 $\alpha$ in venous and capillary endothelium was not included in the tissue staining results. *Expression of PI3K-C2 $\beta$ was nuclear in spermatocytes.

found in many cell types and tissues (summarised in Table 1). In positive cells, expression was mainly cytoplasmic and occasionally membranous whereas cell nuclei only stained with PI3K-C2 $\beta$ (in the testis). p85, PI3K-C2 $\alpha$ and PI3K-C2 $\beta$ were expressed in columnar and transitional epithelia while mucous secreting and stratified squamous epithelia were negative. Mononuclear cells in the lamina propria, dermis, submucosae of different tissues expressed p85, PI3K-C2 $\alpha$ and PI3K-C2 $\beta$. The majority of mononuclear cells were of the macrophage lineage as confirmed by staining of serial sections with CD68. Smooth muscle cells expressed PI3K-C2 $\alpha$ in different organs investigated (vessels, muscularis layer of the GI tract, urinary tract, uterus, fallopian tubes and prostate) but expression was distinctly fainter than that observed in epithelial cells. Endothelial cells lining capillaries and small venules frequently expressed PI3K-C2 $\alpha$. The patterns of expression in the different body systems are detailed below:

\section{Gastrointestinal (Gl) tract}

In the stomach, immunoreactivity for each PI3K antibody was limited to the basal third of the fundic glands where peptic (chief/zymogenic cells) predominate (Figure 2A). Expression was cytoplasmic coarse and granular. Along the crypt/villus axis of the small intestine, p85, PI3K-C2 $\alpha$ and PI3K-C2 $\beta$ were expressed in enterocytes covering the intestinal villi while Paneth cells expressed only p85 (Figure $2 \mathrm{~B}$ ). Expression was cytoplasmic, coarse granular with p85 and diffuse for class II PI3K. In the colon and appendix, PI3K enzyme expression was observed in colonocytes. Mucous-secreting (gastric surface and neck mucous cells ; intestinal goblet cells and Brunner glands), neuroendocrine, and stromal cells of the lamina propria were negative.

Macrophages and other mononuclear cells found in the lamina propria expressed p85 PI3K-C2 $\beta$ and to a lesser extent PI3K-C2 $\alpha$. Lymphoid follicles were negative for all three enzymes with occasional positivity in germinal center macrophages (Figure 2D). Strong expression of p85 and PI3K-C2 $\beta$ but not PI3K-C2 $\alpha$ was observed in the Ganglion cells in the parasympathetic ganglia of the submucosal (Meissner's) and myenteric (Auerbach's) plexus. PI3K-C2 $\beta$ was found in the unmyelinated nerve fibres penetrating between the smooth muscle fibres (Figure 2E) and myelinated peripheral nerves in the vicinity of major vessels.

\section{Respiratory tract}

Neither the squamous (type I) nor the cuboidal (type II) pneumocytes expressed p85 or Class II PI3K enzymes. In contrast, all three PI3K enzymes were expressed in scattered alveolar macrophages (Figure $2 \mathrm{~F}$ ) and in the colum- 


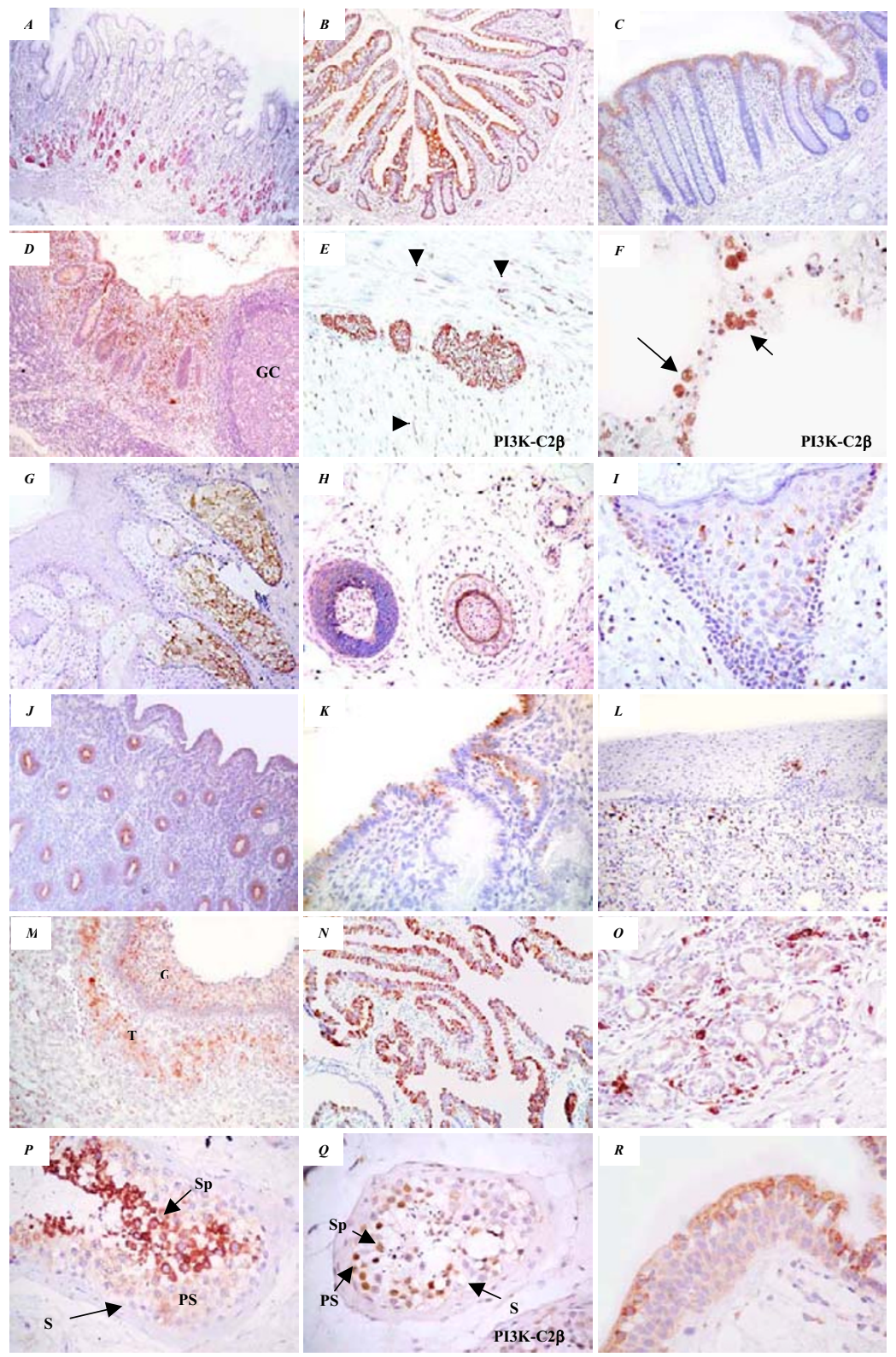

\section{Figure 2}

Representative sections of p85 and PI3K-C2 $\beta$ (E, F and $Q$ ) expression in adult human tissues. In the GI tract, expression was observed in the lower third of gastric glands $(\boldsymbol{A})$, in villous enterocytes $(\boldsymbol{B})$, in surface colonocytes $(\boldsymbol{C})$ and in macrophages infiltrating the lamina propria, especially in the appendix (D). Note the lack of expression of p85 in reactive germinal centres (GC) or in mature B lymphocytes. Myenteric plexuses and unmyelinated nerves (arrow heads) penetrating smooth muscles expressed PI3K-C2 $\beta$ as shown (E). PI3K-C2 $\beta$ was strongly expressed in alveolar macrophages in the lung (marked by arrows) $(\boldsymbol{F})$. In the skin, p85 reactivity was observed in sebaceous glands $(\boldsymbol{G})$, in hair follicles $(\boldsymbol{H})$ and in Langerhans cells $(I)$. Luminal p85 immunoreactivity, which was observed in endometrial glands in the proliferative phase $(J)$ gradually disappeared when the secretory phase developed to remain only on the surface $(\boldsymbol{K})$. In the cervix $(\boldsymbol{L})$, and breast $(\mathbf{O})$ only infiltrating macrophages expressed p85, serving as an internal positive control. In the ovarian follicle, p85 expression was seen in granulosa and theca cells $(\mathbf{M})$. Columnar ciliated fallopian tube epithelium was strongly reactive for p85 ( $\mathbf{N})$. In the testicular seminiferous tubules, p85 was expressed in the cytoplasm $(\boldsymbol{P})$ while PI3K-C2 $\beta$ was expressed in the nuclei (Q) of primary spermatocyes (PS), spermatids (Sp) but not in sertoli cells (S). Transitional epithelium p85 expression was intensified in the uppermost (umbrella) layer $(\boldsymbol{R})$. Original magnification (A, B, G, J, N x 100), (C, D, F, H, L, M × 200), (E, F, I, K, O-R × 400). 
nar epithelium lining the bronchioles. PI3K-C2 $\alpha$ was expressed in an apical 'linear' pattern in ciliated cells. Bronchial mucous glands and cartilage did not express any of the 3 enzymes studied.

\section{Skin and appendages}

Neither enzyme was expressed in keratinised squamous epithelium or melanocytes. In sebaceous glands, p85, PI3K-C2 $\alpha$ and PI3K-C2 $\beta$ were expressed in acini but not in germinative cells (Figure 2G). Sweat glands expressed p85 in luminal secretory cells while PI3K-C2 $\alpha$ was expressed in the myoepithelial layer and in sweat gland ducts. PI3K-C2 $\beta$ was undetectable in sweat glands (Figure $2 \mathrm{H})$.

At the level of the hair bulb, expression of p85 was barely detectable. At a higher level, p85 expression was noted in the companion layer (the innermost layer of the outer root sheath) and in the cuticle (the innermost layer of the internal root sheath). Hair matrix cells and follicular papillae did not express p85 (Figure 2H). PI3K-C2 $\alpha$ and PI3K-C2 $\beta$ were not expressed in the hair follicle. Expression of p85 was observed in a subset of dermal mononuclear cell and Langerhans cells (Figure 2I) while PI3K-C2 $\alpha$ and C2 $\beta$ were expressed in dermal macrophages only.

\section{Female reproductive system Uterus}

The expression of p85 in endometrium varied with the menstrual cycle. In the proliferative phase, p85 was observed on the luminal surface of endometrial glands and heterogeneously on the luminal endometrial surface. In the secretory phase, p85 expression was attenuated from the glandular epithelium, now distended with secretion, to be retained only in the surface endometrium (Figure 2J,2K). There was no stromal expression of either enzyme throughout the cycle. PI3K-C $2 \alpha$ and PI3K-C2 $\beta$ were not expressed in uterine glands. Myometrium and vascular smooth muscle expressed PI3K-C2 $\alpha$. Squamous epithelium of the cervix was negative for all 3 antibodies (Figure 2L).

\section{Ovary and Fallopian tube}

Ovarian tissue expressed p85 in granulosa cells of antral follicles and in theca cells (Figure 2M). PI3K-C2 $\alpha$ and PI3K-C2 $\beta$ were expressed in theca cells only. Ovarian surface epithelium, rete ovarii and corpora lutei did not express PI3K. In the stroma, scattered positive macrophages were observed. Fallopian tube expressed p85 (Figure $2 \mathrm{~N}$ ), PI3K-C2 $\alpha$ and PI3K-C2 $\beta$ in the cytoplasm of lining ciliated columnar epithelium. Whereas p85 and PI3K-C2 $\beta$ were expressed diffusely, PI3K-C2 $\alpha$ was mainly expressed in a linear pattern beneath the cilia.

\section{Breast}

Normal breast lobules expressed no p85 (Figure 2O), PI3K-C $2 \alpha$ or PI3K-C2 $\beta$. In areas of apocrine metaplasia, weak expression of p85 was noted. Myoepithelial cells occasionally expressed PI3K-C2 $\alpha$, which was also weakly expressed in normal ductal epithelium.

\section{Male reproductive system \\ Testis}

Germ cells in the basal and intermediate compartments of the seminiferous tubule, namely the spermatogonium, pre-leptotene, leptotene and zygotene spermatocytes, expressed weak p85 and PI3K-C2 $\beta$. In the developmental stages extending from pachytene spermatocytes to elongating spermatids, reactivity for p85 (Figure 2P) was detected in the cytoplasm and for PI3K-C2 $\beta$ in the nuclei of germ cells. Strong p85 expression was found in secondary spermatocytes and this was maintained in mature spermatozoa. Spermatogonia lacked p85 and PI3K-C2 $\beta$ while final differentiating sperm were devoid of PI3K-C2 $\beta$ expression (Figure 2Q). No expression of PI3K-C2 $\alpha$ was observed with spermatocytic maturation. In contrast to interstitial Leydig cells, in which weak heterogeneous expression of p85, PI3K-C2 $\alpha$ and PI3K-C $2 \beta$ was observed, sertoli cells were not reactive for either antibody.

\section{Prostate}

Normal prostatic glands in the clinical setting of benign prostatic hyperplasia (BPH) did not express any p85 or PI3K-C2 $\beta$. PI3K-C2 $\alpha$ was expressed in an interrupted manner in basal (myoepithelial) prostatic cells and in prostatic fibromuscular stroma.

\section{Urinary tract}

In transitional epithelium, p85 and PI3K-C2 $\beta$ expression was generally strong in the cytoplasm of superficial cells and weak in the intermediate and basal cells (Figure 2R). Expression was heterogenous and scattered negative superficial cells were observed. Smooth muscle bundles and endothelium expressed PI3K-C2 $\alpha$.

In the kidney, macrophages (confirmed by reactivity for CD68) were the only cells in the glomeruli, which expressed p85 and PI3K-C2 $\beta$ (Figure 3A). Expression of PI3K-C2 $\alpha$ in the glomerular tuft was observed in the parietal layer of Bowman's capsule being reflected on and in continuity with reactivity in the visceral (podocyte) layer. It appeared to be distinct from glomerular endothelial lining as demonstrated in Figure 3B. In the renal tubules, cytoplasmic expression of p85 was seen in the macula densa and in collecting tubules (Figure 3A). PI3K-C2 $\alpha$ and PI3K-C2 $\beta$ were weakly expressed in proximal, distal and collecting tubules and ducts. 


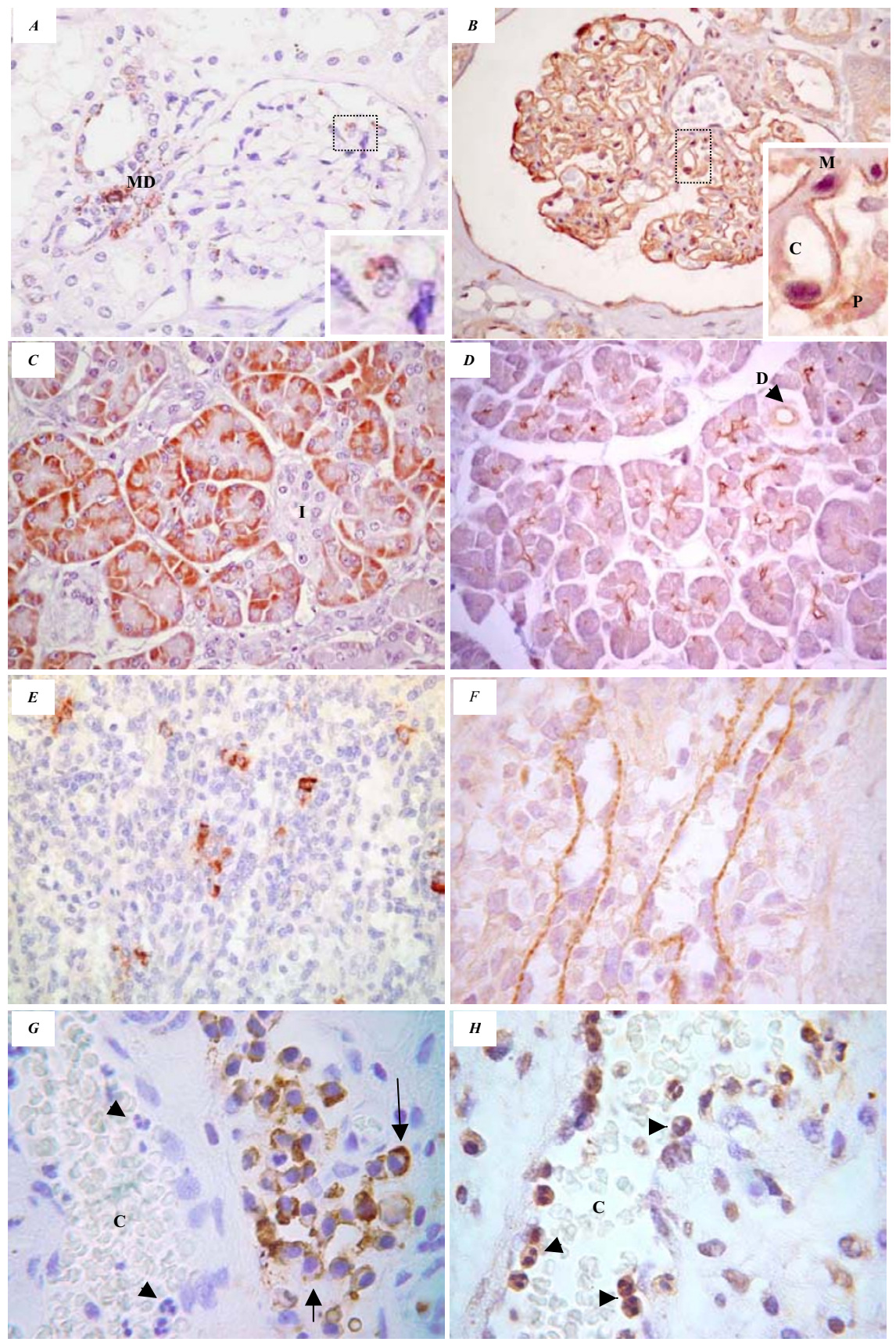

Figure 3

Contrasting expression of p85 (left panels) and PI3K-C2 $\alpha$ (right panels) in the kidney (A, B), pancreas (C, D), spleen (E, F) and immune cells (G, H). In the kidney, p85 was expressed in glomerular macrophages (see inset) and in the macula densa (MD) (A) while PI3K-C2 $\alpha$ labelled the glomerular tuft $(\boldsymbol{B})$. Closer examination of the marked area (inset), expression is observed to be epithelial $(P)$ rather than endothelial $(C)$ or mesangial $(M)$. Pancreatic acinar cells expressed p85 in a cytoplasmic subnuclear position $(\boldsymbol{C})$ while PI3K-C2 $\alpha$ highlighted intercalated ducts $(\boldsymbol{D})$. Mononuclear cells (macrophages) in the splenic red pulp were reactive for p85 (E). PI3K-C2 $\alpha$ was observed in macrophages and in splenic sinusoids, in an interrupted bead-like manner $(\boldsymbol{F})$. Acute inflammatory cells (arrow head) adhering to the wall of a dilated capillary (C) are not reactive for p85 $(\boldsymbol{G})$ but express PI3K-C2 $\alpha(\boldsymbol{H})$. Tissue macrophages expressed p85 (membranous expression is marked by arrows) and cytoplasmic PI3K-C2 $\alpha$. (Original magnification A, C, D and E × 400), (B × 200), (F-H × I000) 


\section{Pancreas and Hepatobiliary tract}

Heterogenous cytoplasmic expression for p85 and PI3K$\mathrm{C} 2 \alpha$ was noted in the exocrine component of the pancreas with no detectable immunoreactivity in islets of Langerhans' cells. The class I (p85) enzyme was expressed in the acinar cytoplasm in a subnuclear basal position (Figure $3 \mathrm{C})$ while PI3K-C2 $\alpha$ was expressed on the luminal border of the acinus corresponding to the intercalated ducts (Figure 3D). Pancreatic ducts (intralobular, interlobular and the larger ducts) only expressed PI3K-C2 $\alpha$. PI3K-C2 $\beta$ was not observed in the pancreas.

Hepatocytes, hepatic sinusoids and Kupffer cells did not express detectable levels of p85, PI3K-C2 $\alpha$ or PI3K-C2 $\beta$. PI3K-C2 $\alpha$ immunolabeled bile ducts. In the gall bladder, the lining epithelium was reactive for all three antibodies.

\section{Thyroid and Parathyroid glands}

No immunoreactivity for p85, PI3K-C2 $\alpha$ and PI3K-C2 $\beta$ was detected in thyroid glands (follicular or parafollicular cells) or parathyroid glands (chief/principal) cells and oxyphil cells).

\section{Lymphoid tissue and immune cells}

In lymph nodes and in the spleen, p85 and PI3K-C2 $\beta$ reactivity was limited to a few cells in the interfollicular and medullary areas (Figure 3E). Endothelial cells lining venous sinusoids in the spleen expressed PI3K-C2 $\alpha$ in a subnuclear position forming an interrupted linear, almost bead-like pattern (Figure 3F). p85, PI3K-C2 $\alpha$ and PI3K$\mathrm{C} 2 \beta$ labeled individual tissue macrophages (Figure 3G) and follicular dendritic cells in the germinal center but were not expressed in the $\mathrm{B}$ lymphocyte precursors or mature B cells (Figure 2D). Only PI3K-C2 $\alpha$ was detected in significant levels in polymorphnuclear leucocytes (Figure $3 \mathrm{G}, 3 \mathrm{H})$.

\section{Discussion}

Most of the current literature relies on biochemical methods to provide evidence for the presence of PI3K mRNA or protein in human tissue or cell line lysates [14-16]. With a single report of p85 expression (in lung cancer) [20] and none relating to PI3K-C2 $\alpha$ and PI3K-C2 $\beta$, there was a need for a systematic study examining topographical expression and precise cellular localisation of PI3K enzymes in human tissues.

Our report illustrates the selective expression of PI3K enzymes in normal adult human tissues, appearing to be restricted to the differentiated cell lineages compared to the proliferative and stem cell compartments. In differentiated cells (epithelial and mesenchymal), expression of p85, C $2 \alpha$ and C2 $\beta$, either singly or in combination, was observed only in a limited repertoire of cells. Differences in expression and in spatial localisation of PI3K isoforms possibly reflect the diverse roles played by these enzymes in various tissues in response to different ligands. In hepatocytes, endocrine organs (thyroid and parathyroid glands and Islets of Langerhans), squamous epithelium and secretory epithelia in general, no p85 or class II PI3K enzymes were detected. This either reflects very low levels of expression under normal in vivo conditions (not detectable by methods employed in this study), or the predominance of alternative PI3K isoforms in these tissues. In the liver, for example, there is biochemical evidence of high expression of PI3K-p50 $\alpha$ and PI3K-C2 $\gamma$ in the liver $[16,17,21]$. Marked responsiveness of $p 50 \alpha$ to insulin suggests that this adaptor plays an important role in the activation of hepatic PI3K [21]. Another observation was that those cells expressing only two PI3K isoforms, coexpression of p85 and PI3K-C2 $\alpha$ was not observed (Figures 3 and 4). This, together with the unique expression of PI3K-C2 $\alpha$ in mesenchymal elements (endothelial cells and smooth muscle cells), myoepithelial and ductal cells suggests a more specialized role for PI3K-C2 $\alpha$ compared to $\mathrm{p} 85$ or PI3K-C2 $\beta$. Further in vitro biochemical studies are required to elucidate this role.

PI3K expression was analysed in tissues representative of self regenerating stem cell systems such as skin, intestines, bladder, uterine cervix and testis (which normally show growth and differentiation throughout life), quiescent (stable) tissues such as parenchymal cells of the liver, kidney, pancreas, vascular endothelial cells and thyroid (tissues that show little growth in adult life but can be driven to proliferate by an appropriate stimulus), and of nondividing (permanent) terminally differentiated cells that have no reserve capacity for growth such as neurones (ganglion cells) and macrophages [22]. In self-regenerating tissues, shedding of epithelial cells is compensated by a precursor stem cell population that rapidly divides then selectively differentiates to replace lost cells [23]. Proliferation and differentiation are inversely correlated processes where differentiation of primitive into more specialized cells involves increased restriction in proliferative capacity, culminating in cell-cycle exit and arrest [24]. Welldefined stem cell compartments have been identified in the GI tract, skin and testis (reviewed in [25-27]). In these organs, p85, PI3K-C2 $\alpha$ and PI3K-C2 $\beta$ were only expressed in fully differentiated cells. With the exception of the apical p85 expression in proliferative endometrium, there was no identifiable expression of PI3K enzymes in stem/ progenitor or proliferating cell compartments. The absence of either p85 or class II PI3K immunoreactivity in germinal centres of reactive lymphoid follicles is consistent with our observation that PI3K enzymes are expressed in differentiated, committed cells and not in proliferating or immature cells. PI3K expression in permanent nondividing, non-epithelial cells such as ganglion cells and macrophages is indicative of a general rather than cell-spe- 


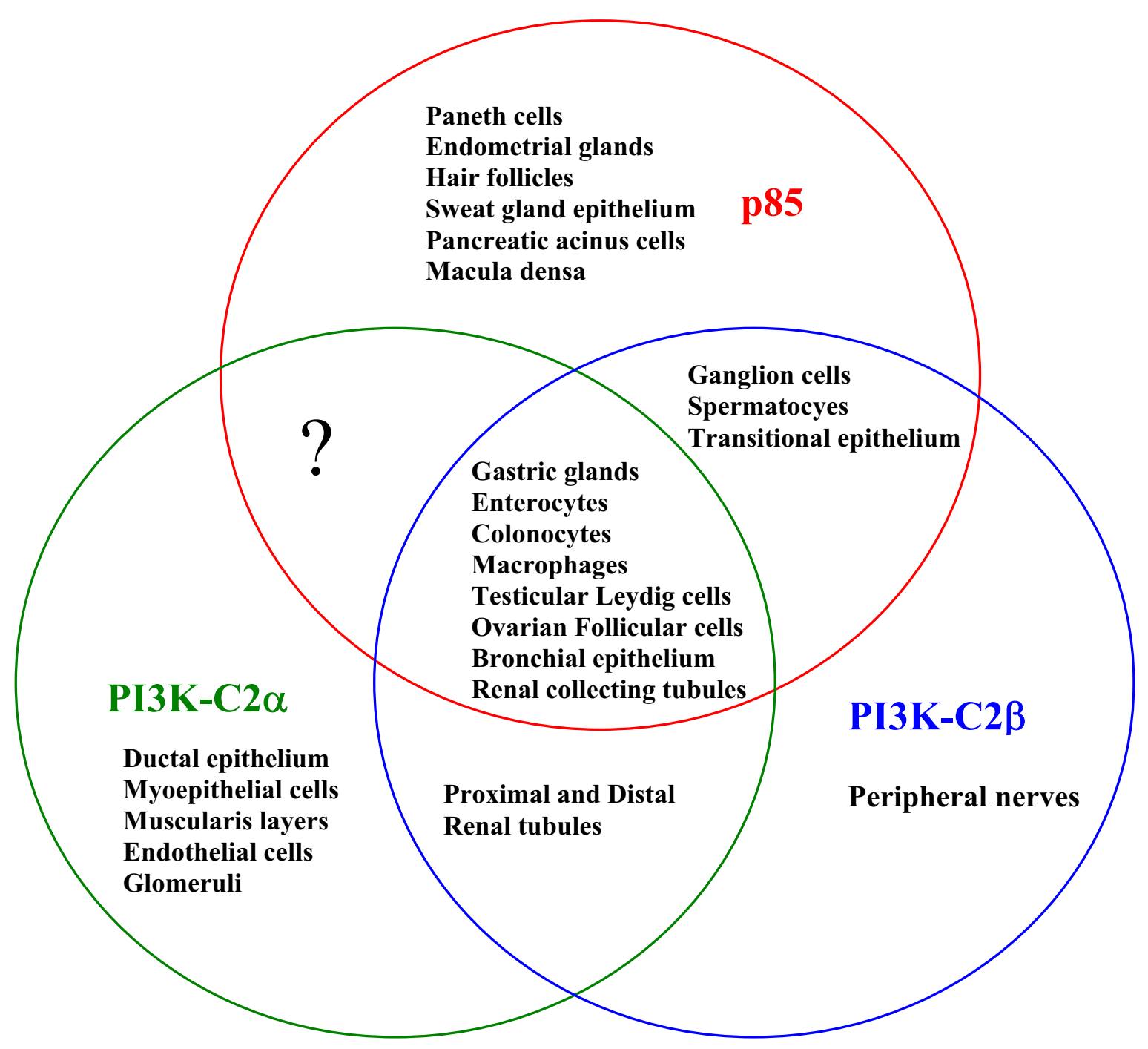

Figure 4

Overlapping patterns of PI3K enzyme expression in adult human tissues. Co-localisation of the P85, PI3K- $\alpha$ and $\mathrm{PI} 3 \mathrm{~K}-\mathrm{C} 2 \beta$ was more frequently observed than expression of one or 2 of these enzymes. Expression of p 85 and PI3K-C2 $\alpha$ was not observed.

cific growth regulatory mechanism. Based on in vitro data examining cell cycle progression in cell lines and embryonic stem cells [28-32], we would have predicted an inverse pattern of expression to what was observed.

Our data suggest an association between PI3K and cellular differentiation. This association is best demonstrated in intestinal epithelium and testicular seminiferous tubules, both of which are models to study the mechanisms of tissue differentiation. In these tissues, spatially organised stem cell, proliferative and differentiated compartments create a "gradient" of cell differentiation. In the intestine and the testis, PI3K expression increased with differentiation. The increase in PI3K expression in these tissues was more dramatic in the case of p85 than for class II enzymes. Previous in vitro data linking PI3K activation to differenti- 
ation have been controversial. In the intestine, our data supports the study by Laprise et al [33] who showed that PI3K activity promotes intestinal epithelial cell differentiation and contradicts others $[34,35]$ who propose that PI3K inhibition contributes to intestinal cell differentiation. The expression pattern of $\mathrm{p} 85$ observed in the testis is supported by data from Kissel et al [36] who showed that Kit-mediated PI3K signalling is critical for the development of male germ cells during the pre-meiotic stages. When these signals were interrupted, male sterility developed due to failure of germ cell to enter meiosis and increased apoptosis of primary spermatocytes [36]. Interestingly, we observed nuclear PI3K-C2 $\beta$ immunoreactivity in developing spermatocytes. This pattern of expression was confined to the testis. A role for nuclear PI3K signalling has been recently identified [37]. Conditions where the presence of nuclear PI3K-C2 $\beta$ was identified, were associated with compensatory rat liver regeneration and differentiation of HL-60 cell line along granulocytic lineage commitment pathways $[38,39]$. The significance of PI3K-C2 $\beta$ expression in the testis and its nuclear localisation is currently unknown.

PI3K expression was observed in immune cells including macrophages and polymorphnuclear leucocytes. The intensity of expression in macrophages frequently exceeded that observed in epithelial cells. Interestingly, only a subset of CD68 positive macrophages (including Kuppfer cells) expressed PI3K enzymes. One possible explanation for this observation is that expression may be related to a specific phase in macrophage function. We are currently examining this possibility. Polymorphnuclear leucocytes expressed moderate-strong PI3K-C2 $\alpha$ but not $\mathrm{p} 85$. This may be related to the relative abundance of the leukocyte-specific class IB PI3K isoform. In vitro observations show that PI3Ks are important regulators of phagocytosis [40]. Class IA and III PI3Ks are thought to act consecutively in phagosome formation and maturation, and that their respective products, PtdIns $(3,4,5) \mathrm{P}_{3}$ and PtdIns (3) $\mathrm{P}$ accumulate transiently at different stages [41]. The involvement of class II PI3Ks, which can also produce PtdIns (3) P can not be excluded [41]. Although the exact mechanisms involved in receptor coupling remain obscure, MCP-1-induced activation of PI3K-C2 $\alpha$ may contribute to some of its cellular responses. More vigorous investigations are needed to determine whether activation of PI3K-C $2 \alpha$ or the related PI3KC $2 \beta$ occurs in response to other chemokines and to determine the functional significance of class II PI3K activation in macrophages. Unexpectedly, B-lymphocytes and their precursors were non reactive. A role for p85 in B lymphocyte development and activation was demonstrated in p85 $\alpha$ deficient mice in two independent studies $[42,43]$. However, the regulation of PI3K activation in p85 $\alpha$-deficient mice is rather complex. In these knockouts, there is reduced expression of all class IA catalytic subunits with enhanced PI3K-dependent responses following stimulation [44-47]. Therefore, extrapolating from these knockout studies to human lymphocyte function is difficult.

The results presented here in suggest a role of PI3K enzymes in differentiated cells, however, they do not rule out a role for these enzymes in proliferation. It is possible that proliferating cells express PI3K enzymes but at levels which were undetectable by methods used in this study. Other more sensitive methods such as real-time PCR could be employed in future studies to explore the above.

\section{Conclusions}

One of the limitations of any IHC study is antibody specificity and antigen preservation. Identifying reliable PI3K antibodies for use in IHC has been especially challenging. Several commercially available and in-house class I PI3K antibodies (p85 or p110) including those used in previous IHC studies $[20,48]$ did not give satisfactory results in our hands. This was either due to limited sensitivity or reduced specificity (high background or multiple bands on the Western blot). We selected 3 PI3K antibodies (class IA PI3K (p85), PI3K-C2 $\alpha$ and PI3K-C2 $\beta$ ) that recognised a protein of the appropriate size on Western blotting and identified their target in formalin-fixed paraffin embedded tissues. Reactivity in IHC was specific as evidenced by successful blocking of immunoreactivity by the antigenic peptide fragments to which the antibodies were raised. We have demonstrated that, in contrast with their expression in cell lines of differing origins, class IA PI3K adaptor, p85, and class II PI3K enzymes display a specific and selective tissue distribution. PI3K enzyme expression in fully differentiated cells argues against their role in cell proliferation. Studies have indicated that p 85 may act as a signalling protein independent of p110 [49,50]. It is, therefore, conceivable that p85 signals detected in this report reflect p110-related lipid kinase activity and other p110-unrelated functions. The use of reliable p110 antibodies or novel anti-PtdIns $(3,4,5) \mathrm{P}_{3}$ antibodies [51] should allow more detailed and comprehensive mapping of the PI3K enzymes in normal and diseased human tissues, and provide insight into potential therapeutic targets of isoform specific PI3K antagonists.

\section{Competing Interests}

None declared.

\section{Authors contribution}

SSE: Performed experiments (Western blotting, PI3Kp85immunostaining), reviewed and interpreted the data, photomicrography and preparation of the manuscript.

JD: together with ENL had the original idea for the project. Provision of affinity purified antibody to class II PI3K 
enzymes. Practical supervision of the project. Contributed to the design and relevance of the study, reviewed and interpreted the data.

PA: contributed to the design and relevance of the study and reviewed and interpreted the data.

PT: performed experiments with class II PI3K antibodies including peptide blocking.

\section{GS: reviewed and interpreted the data.}

ENL: was the primary supervisor of the project, had the original idea for the project, together with JD contributed to the design and relevance of the study, reviewed and interpreted the data and is the corresponding author.

The conclusions were agreed by all authors.

All authors contributed sections of text to the manuscript, read the manuscript and agreed to the final version.

\section{References}

I. Courtneidge SA and Heber A: An 8I kd protein complexed with middle $T$ antigen and pp60c-src: a possible phosphatidylinositol kinase. Cell 1987, 50:1031-1037.

2. Katso R, Okkenhaug K, Ahmadi K, White S, Timms J and Waterfield MD: Cellular function of phosphoinositide 3-kinases: implications for development, homeostasis, and cancer. Annu Rev Cell Dev Biol 200I, 17:615-675.

3. Cantrell DA: Phosphoinositide 3-kinase signalling pathways. J Cell Sci 200I, I I 4:|439-|445.

4. Vanhaesebroeck B and Waterfield MD: Signaling by distinct classes of phosphoinositide 3-kinases. Exp Cell Res 1999, 253:239-254.

5. Domin J and Waterfield MD: Using structure to define the function of phosphoinositide 3-kinase family members. FEBS Lett 1997, 410:91-95.

6. Vanhaesebroeck B, Welham MJ, Kotani K, Stein R, Warne PH, Zvelebil MJ, Higashi K, Volinia S, Downward J and Waterfield MD: PII0delta, a novel phosphoinositide 3-kinase in leukocytes. Proc Natl Acad Sci U S A 1997, 94:4330-4335.

7. Bernstein HG, Keilhoff G, Reiser M, Freese $S$ and Wetzker R: Tissue distribution and subcellular localization of a G-protein activated phosphoinositide 3-kinase. An immunohistochemical study. Cell Mol Biol (Noisy-le-grand) 1998, 44:973-983.

8. Vanhaesebroeck B, Leevers SJ, Ahmadi K, Timms J, Katso R, Driscoll PC, Woscholski R, Parker PJ and Waterfield MD: Synthesis and function of 3-phosphorylated inositol lipids. Annu Rev Biochem 200I, 70:535-602.

9. Wheeler $M$ and Domin J: Recruitment of the class II phosphoinositide 3-kinase C2beta to the epidermal growth factor receptor: role of Grb2. Mol Cell Biol 200I, 21:6660-6667.

10. Domin J, Gaidarov I, Smith ME, Keen JH and Waterfield MD: The class II phosphoinositide 3-kinase PI3K-C2alpha is concentrated in the trans-Golgi network and present in clathrincoated vesicles. J Biol Chem 2000, 275: I I943- I I950.

II. Arcaro A, Zvelebil MJ, Wallasch C, Ullrich A, Waterfield MD and Domin J: Class II phosphoinositide 3-kinases are downstream targets of activated polypeptide growth factor receptors. Mol Cell Biol 2000, 20:3817-3830.

12. Brown RA, Domin J, Arcaro A, Waterfield MD and Shepherd PR: Insulin activates the alpha isoform of class II phosphoinositide 3-kinase. J Biol Chem I999, 274: | 4529-| 4532.

13. Turner SJ, Domin J, Waterfield MD, Ward SG and Westwick J: The CC chemokine monocyte chemotactic peptide-I activates both the class I p85/p I I 0 phosphatidylinositol 3-kinase and the class II PI3K-C2alpha. J Biol Chem 1998, 273:25987-25995.
14. Arcaro A, Volinia S, Zvelebil MJ, Stein R, Watton SJ, Layton MJ, Gout I, Ahmadi K, Downward J and Waterfield MD: Human phosphoinositide 3-kinase $C 2$ beta, the role of calcium and the $C 2$ domain in enzyme activity. J Biol Chem 1998, 273:33082-33090.

15. Domin J, Pages F, Volinia S, Rittenhouse SE, Zvelebil MJ, Stein RC and Waterfield MD: Cloning of a human phosphoinositide 3-kinase with a C2 domain that displays reduced sensitivity to the inhibitor wortmannin. Biochem J 1997, 326:139-147.

16. Rozycka M, Lu YJ, Brown RA, Lau MR, Shipley JM and Fry MJ: cDNA cloning of a third human C2-domain-containing class II phosphoinositide 3-kinase, PI3K-C2gamma, and chromosomal assignment of this gene (PIK3C2G) to I 2p I 2. Genomics 1998, 54:569-574.

17. Ho LK, Liu D, Rozycka M, Brown RA and Fry MJ: Identification of four novel human phosphoinositide 3-kinases defines a multi-isoform subfamily. Biochem Biophys Res Commun 1997, 235: 130-137.

18. Volinia S, Dhand R, Vanhaesebroeck B, MacDougall LK, Stein R, Zvelebil MJ, Domin J, Panaretou C and Waterfield MD: A human phosphatidylinositol 3-kinase complex related to the yeast Vps34p-VpsI5p protein sorting system. Embo J 1995, 14:3339-3348.

19. Stein RC and Waterfield MD: PI3-kinase inhibition: a target for drug development? Mol Med Today 2000, 6:347-357.

20. Lin X, Bohle AS, Dohrmann P, Leuschner I, Schulz A, Kremer B and Fandrich F: Overexpression of phosphatidylinositol 3-kinase in human lung cancer. Langenbecks Arch Surg 200I, 386:293-30I.

21. Inukai K, Funaki M, Ogihara T, Katagiri H, Kanda A, Anai M, Fukushima Y, Hosaka T, Suzuki M, Shin BC, Takata K, Yazaki Y, Kikuchi M, $\mathrm{Oka} Y$ and Asano T: p85alpha gene generates three isoforms of regulatory subunit for phosphatidylinositol 3-kinase (PI 3Kinase), p50alpha, p55alpha, and p85alpha, with different PI 3-kinase activity elevating responses to insulin. J Biol Chem 1997, 272:7873-7882.

22. Leblond CP: Classification of cell populations on the basis of their proliferative behaviour. NCl Monogr 1963, I4:19-145.

23. Preston SL, Alison MR, Forbes SJ, Direkze NC, Poulsom R and Wright NA: The new stem cell biology: something for everyone. Mol Pathol 2003, 56:86-96.

24. Zhu $L$ and Skoultchi Al: Coordinating cell proliferation and differentiation. Curr Opin Genet Dev 200I, II:91-97.

25. Brittan M and Wright NA: Gastrointestinal stem cells. J Pathol 2002, 197:492-509.

26. Niemann $C$ and Watt FM: Designer skin: lineage commitment in postnatal epidermis. Trends Cell Biol 2002, I 2: I85-192.

27. Cooke HJ: Immortalizing the immortal. Nat Genet 2002, 32:90-91.

28. Klippel A, Escobedo MA, Wachowicz MS, Apell G, Brown TW, Giedlin MA, Kavanaugh WM and Williams LT: Activation of phosphatidylinositol 3-kinase is sufficient for cell cycle entry and promotes cellular changes characteristic of oncogenic transformation. Mol Cell Biol I998, I8:5699-57II.

29. Collado M, Medema RH, Garcia-Cao I, Dubuisson ML, Barradas M, Glassford J, Rivas C, Burgering BM, Serrano M and Lam EW: Inhibition of the phosphoinositide 3-kinase pathway induces a senescence-like arrest mediated by p27Kip I. J Biol Chem 2000, 275:21960-21968.

30. Tresini M, Mawal-Dewan M, Cristofalo VJ and Sell C: A phosphatidylinositol 3-kinase inhibitor induces a senescent-like growth arrest in human diploid fibroblasts. Cancer Res 1998, 58:I-4.

31. Chakravarthy Manu V., Abraha Tsghe W., Schwartz Robert J., Fiorotto Marta L. and Booth Frank W.: Insulin-like Growth Factor-I Extends in Vitro Replicative Life Span of Skeletal Muscle Satellite Cells by Enhancing G I/S Cell Cycle Progression via the Activation of Phosphatidylinositol 3'-Kinase/Akt Signaling Pathway. J. Biol. Chem. 2000, 275:35942-35952.

32. Hallmann Daniel, Trumper Katja, Trusheim Heidi, Ueki Kohjiro, Kahn C. Ronald, Cantley Lewis C., Fruman David A. and Horsch Dieter: Altered Signaling and Cell Cycle Regulation in Embryonal Stem Cells with a Disruption of the Gene for Phosphoinositide 3-Kinase Regulatory Subunit p85alpha . J. Biol. Chem. 2003, 278:5099-5108.

33. Laprise P, Chailler P, Houde M, Beaulieu JF, Boucher MJ and Rivard N: Phosphatidylinositol 3-kinase controls human intestinal epithelial cell differentiation by promoting adherens junction 
assembly and p38 MAPK activation. J Biol Chem 2002, 277:8226-8234

34. Wang Q, Wang X, Hernandez A, Kim S and Evers BM: Inhibition of the phosphatidylinositol 3-kinase pathway contributes to HT29 and Caco-2 intestinal cell differentiation. Gastroenterology 200I, I 20:138I-1392.

35. Kim S, Domon-Dell C, Wang Q, Chung DH, Di Cristofano A, Pandolfi PP, Freund JN and Evers BM: PTEN and TNF-alpha regulation of the intestinal-specific Cdx-2 homeobox gene through a PI3K, PKB/Akt, and NF-kappaB-dependent pathway. Gastroenterology 2002, I 23: I I63-I I78.

36. Kissel Holger, Timokhina Inna, Hardy Matthew P., Rothschild Gerson, Tajima Youichi, Soares Vera, Angeles Michael, Whitlow Scott R., Manova Katia and Besmer Peter: Point mutation in Kit receptor tyrosine kinase reveals essential roles for Kit signaling in spermatogenesis and oogenesis without affecting other Kit responses. $E M B O$ J. 2000, 19:1312-1326.

37. Neri LM, Borgatti P, Capitani $S$ and Martelli AM: The nuclear phosphoinositide 3-kinase/AKT pathway: a new second messenger system. Biochim Biophys Acta 2002, I 584:73.

38. Visnjic D, Crljen V, Curic J, Batinic D, Volinia $S$ and Banfic $H$ : The activation of nuclear phosphoinositide 3-kinase $C_{2}$ beta in alltrans-retinoic acid-differentiated HL-60 cells. FEBS Lett 2002 529:268-274.

39. Sindic A, Aleksandrova A, Fields AP, Volinia S and Banfic H: Presence and activation of nuclear phosphoinositide 3-kinase C2beta during compensatory liver growth. J Biol Chem 200I, 276: I7754-1776|.

40. Gillooly David J., Simonsen Anne and Stenmark Harald: Phosphoinositides and phagocytosis. J. Cell Biol. 200I, 155:I5-I8.

4I. Vieira OV, Botelho RJ, Rameh L, Brachmann SM, Matsuo T, Davidson HW, Schreiber A, Backer JM, Cantley LC and Grinstein S: Distinct roles of class I and class III phosphatidylinositol 3-kinases in phagosome formation and maturation. I Cell Biol 200I 155:19-25.

42. Fruman DA, Snapper SB, Yballe CM, Davidson L, Yu JY, Alt FW and Cantley LC: Impaired B cell development and proliferation in absence of phosphoinositide 3-kinase p85alpha. Science 1999, 283:393-397.

43. Suzuki H, Terauchi Y, Fujiwara M, Aizawa S, Yazaki Y, Kadowaki T and Koyasu S: Xid-like immunodeficiency in mice with disruption of the p85alpha subunit of phosphoinositide 3-kinase. Science 1999, 283:390-392.

44. Yu Jinghua, Zhang Yitao, Mcllroy James, Rordorf-Nikolic Tamara, Orr George A. and Backer Jonathan M.: Regulation of the p85/p I I0 Phosphatidylinositol 3'-Kinase: Stabilization and Inhibition of the pII0alpha Catalytic Subunit by the p85 Regulatory Subunit. Mol. Cell. Biol. 1998, 18:| 379-I387.

45. Ueki K, Fruman DA, Brachmann SM, Tseng YH, Cantley LC and Kahn CR: Molecular balance between the regulatory and catalytic subunits of phosphoinositide 3-kinase regulates cell signaling and survival. Mol Cell Biol 2002, 22:965-977.

46. Terauchi $Y$, Tsuji $Y$, Satoh S, Minoura H, Murakami K, Okuno A, Inukai K, Asano T, Kaburagi Y, Ueki K, Nakajima H, Hanafusa T, Matsuzawa Y, Sekihara H, Yin Y, Barrett JC, Oda H, Ishikawa T, Akanuma Y, Komuro I, Suzuki M, Yamamura K, Kodama T, Suzuki H, Kadowaki $\mathrm{T}$ and et al.: Increased insulin sensitivity and hypoglycaemia in mice lacking the p85 alpha subunit of phosphoinositide 3 . kinase. Nat Genet 1999, 21:230-235.

47. Mauvais-Jarvis F, Ueki K, Fruman DA, Hirshman MF, Sakamoto K, Goodyear LJ, lannacone M, Accili D, Cantley LC and Kahn CR. Reduced expression of the murine p85alpha subunit of phosphoinositide 3-kinase improves insulin signaling and ameliorates diabetes. J Clin Invest 2002, 109: | 4 I- I 49.

48. Woenckhaus J, Steger K, Werner E, Fenic I, Gamerdinger U, Dreyer $T$ and Stahl U: Genomic gain of PIK3CA and increased expression of p I I0alpha are associated with progression of dysplasia into invasive squamous cell carcinoma. J Pathol 2002, 198:335-342.

49. Jimenez C, Portela RA, Mellado M, Rodriguez-Frade JM, Collard J, Serrano A, Martinez AC, Avila J and Carrera AC: Role of the PI3K regulatory subunit in the control of actin organization and cell migration. / Cell Biol 2000, I 5 I :249-262.

50. Okkenhaug K and Vanhaesebroeck B: New responsibilities for the PI3K regulatory subunit p85 alpha. SCi STKE 200I, 200 I:PEI.
51. Niswender Kevin D., Gallis Byron, Blevins James E., Corson Marshall A., Schwartz Michael W. and Baskin Denis G.: Immunocytochemical Detection of Phosphatidylinositol 3-kinase Activation by Insulin and Leptin. J. Histochem. Cytochem. 2003, 5 I:275-283.

\section{Pre-publication history}

The pre-publication history for this paper can be accessed here:

http://www.biomedcentral.com/1472-6890/3/4/prepub
Publish with Bio Med Central and every scientist can read your work free of charge

"BioMed Central will be the most significant development for disseminating the results of biomedical research in our lifetime. "

Sir Paul Nurse, Cancer Research UK

Your research papers will be:

- available free of charge to the entire biomedical community

- peer reviewed and published immediately upon acceptance

- cited in PubMed and archived on PubMed Central

- yours - you keep the copyright
BioMedcentral 